\section{Soil Water Tension Irrigation Criteria Affects Stevia rebaudiana Leaf Yield and Leaf Steviol Glycoside Composition}

\author{
Cheryl A. Parris ${ }^{1}$ \\ S\& $W$ Seed Company Inc., Fresno, CA 93720
}

\author{
Clinton C. Shock ${ }^{2,4}$ \\ Malheur Experiment Station, Oregon State University, 595 Onion Avenue, \\ Ontario, OR 97914
}

\section{Michael Qian ${ }^{3}$ \\ Food Science and Technology Department, Oregon State University, 100 Wiegand Hall, Corvallis, OR 97331-6602}

Additional index words. subsurface drip irrigation, stevioside, rebaudioside A, rebaudioside C, ratio of rebaudioside A to stevioside, total steviol glycosides

\begin{abstract}
Stevia (Stevia rebaudiana Bertoni) is of interest for the production of steviol glycosides due to their noncaloric sweetening properties. Commercial stevia leaf production to date has focused on rebaudioside $A$ and stevioside. Relatively little is known about the cultural practices necessary for the efficient production of stevia leaf and steviol glycosides. Irrigation management is an important agronomic technique that growers can use to obtain high yield while also pursuing water use efficiency (WUE). This trial investigated the effect that irrigation onset criteria measured as soil water tension (SWT) had on dry stevia leaf yields, steviol glycoside content and yield, and steviol glycoside ratios. Two stevia cultivars, SW 107 and SW 129 (S\&W Seed Company Inc., Fresno, CA), were subjected to SWT irrigation criteria of 10, 20, 40, 60, and $80 \mathrm{kPa}$ over a 57-day trial period at the Oregon State University (OSU) Malheur Experiment Station, Ontario, OR. Harvested plant material was evaluated for dry leaf yield and content of several steviol glycosides. Analysis of variance (ANOVA) showed significant cultivar differences in leaf yield, leaf stevioside and rebaudioside $A$ content and yield, and steviol glycoside ratios $(P=\mathbf{0 . 0 5})$. Examining the data by ANOVA, dry leaf yield, stevioside percent, rebaudioside $C$ percent, total steviol glycoside (TSG) percent, rebaudioside $C$ yield, and TSG yield were significantly greater among the wetter (closer to $10 \mathrm{kPa}$ ) compared with the drier (closer to $80 \mathrm{kPa}$ ) SWT criteria treatments, yet a preferred treatment regime was not clearly evident. When comparing cultivars by regression analysis, there was a highly significant decrease in the stevioside content, and an increase in the ratio of rebaudioside $A$ to stevioside from wetter to drier irrigation onset criteria (due to lower stevioside), whereas the rebaudioside $A$ content did not respond significantly to differing irrigation criteria. Increasing dry leaf productivity with wetter irrigation criteria (closer to $10 \mathrm{kPa}$ ), directly increased the total rebaudioside $A$ yield also, which in turn could provide increased crop value to the grower. Irrigating near 10 kPa produced higher dry leaf yield and total rebaudioside A yield, than irrigating at drier criteria.
\end{abstract}

The consumption of the noncaloric natural sweeteners (steviol glycosides) from stevia ( $S$. rebaudiana Bertoni) has been increasing in the United States (Sprinkle, 2014). The most commonly marketed steviol glycosides are rebaudioside A and stevioside. The state of knowledge of the cultivation of stevia has been compiled and reviewed by

Received for publication 9 Sept. 2016. Accepted for publication 24 Oct. 2016.

This work was supported by S\&W Seed Company of Fresno, CA.

${ }^{1}$ Manager, Stevia Breeding and Research.

${ }^{2}$ Professor and Director.

${ }^{3}$ Professor.

${ }^{4}$ Corresponding author. E-mail: clinton.shock@ oregonstate.edu. registration of useful herbicides and fungicides, and a comprehensive identification of pathogens and pests. Shock (1982a, 1982b) studied dry stevia leaf and stem yield for possible cultivation in California. The field studies conducted at the University of California, Davis, CA, reported a dry leaf yield of $3.7 \mathrm{Mg} \cdot \mathrm{ha}^{-1}$ for a single growing season with a density of 191,400 plants/ha. The irrigation treatment was not specified but mentioned that frequent shallow irrigations were used.

Over the past decade, stevia irrigation trials in Colombia, Iran, India, Italy, and Paraguay have examined irrigation effects on dry stevia leaf yields, and in some instances, steviol glycoside content (Aladakatti et al., 2012; Behera et al., 2013; Fronza and Folegatti, 2003; Lavini et al., 2008; Niño et al., 2013; Prieto et al., 2014). Most of the irrigation studies worldwide have been based on replacing all or a proportion of pan evapotranspiration or crop evapotranspiration. In the United States, the S\&W Seed Company developed an interest in stevia leaf production in California in 2010, when little was known about stevia irrigation guidelines. Shock and Parris (2015, 2016) developed the cultivars SW 107 and SW 129 for S\&W Seed Company. 'SW 107' was selected for vigor and 'SW 129' was selected for its steviol glycoside composition. Leaf flavor and delayed flowering were also factors in the selection of 'SW 107' and 'SW 129'. These two cultivars were used in this irrigation trial based on their performance in a prior yield trial, specifically their productivity of rebaudioside $\mathrm{A}$ at Ontario, OR (Parris et al., 2016).

When 'SW 107' and 'SW 129' were first selected in California (2012) and later when they were grown in Oregon in 2013, their steviol glycoside contents were higher than in the subsequent yield trial. It was not known whether the differences in steviol glycoside contents between samplings were due to location, seasonal patterns of steviol glycoside content, leaf sampling procedures, leaf analysis procedures, differences in irrigation practices, or some other cultural practice.

One hypothesis to explain the difference in steviol glycoside content between diverse samplings was that stevia could be using steviol glycosides for osmotic adjustment against the effects of water stress. Generally, plants use accumulated solutes such as $\mathrm{K}^{+}$or sugars to adjust to water stress. Karimi et al. (2015) showed that stevia uses glucose (not fructose and sucrose) for osmotic regulation when water stressed and also showed that stevia had only small increases in total leaf steviol glycoside content with the drier treatments [irrigated at $45 \%$ field capacity (FC)] compared with the total leaf steviol glycoside content with minimal water stress (irrigated at the wetter $90 \% \mathrm{FC}$ ). Yet the TSGs for Karimi et al. (2015) reached only 5.5\% of leaf dry weight with water stress, which places in question the role of steviol glycosides in osmoregulation. TSG content of $5.5 \%$ (Karimi et al., 2015) is relatively low compared with TSG ranging from $8.1 \%$ to $21.2 \%$ for seven stevia cultivars grown at four 
locations in the western United States with little water stress (Parris et al., 2016).

How does the content of steviol glycosides change under different irrigation criteria, and to what extent does mild water stress affect dry stevia leaf yield?

\section{Previous Irrigation Trials}

Niño et al. (2013) in Prado, Colombia, studied drip irrigation of the stevia cultivar Morita II using SWT irrigation criteria of 0-10, 10-20, 30-40, and 50-60 kPa. Differences in dry leaf yield, glycoside concentrations, and WUE were evaluated. Stevia was planted at a density of 54,000 plants/ha in soil where the beds were covered with plastic mulch. The leaves and stems were harvested three times, 38, 72, and $98 \mathrm{~d}$ posttransplant in one season. Total dry leaf yield showed significant increases with wetter SWT treatments $(0-5$ and $10-20 \mathrm{kPa})$ compared with the two drier SWT treatments (30-40 and 50$60 \mathrm{kPa})$ at all harvest dates. Niño et al. (2013) reported that the increases in both leaf stevioside and rebaudioside A content observed with the wetter irrigation criteria were not statistically significant. They defined WUE as the ratio of dry leaf yield to irrigation volume, and WUE was least when the SWT was managed from 0 to $5 \mathrm{kPa}$ and increased when maintained at $50-60 \mathrm{kPa}$.

In Paraguay, near to where stevia occurs naturally, Prieto et al. (2014) compared microsprinkler and drip irrigation with and without patchouli [Pogostemon cablin (Blanco) Benth.] mulch in areas of high annual rainfall (2019 $\mathrm{mm})$, low soil fertility, and high erosion. Drip tape was installed at 10 -cm depth and stevia was irrigated with 3 $5 \mathrm{~mm} / \mathrm{d}$. Dry stevia leaf yields were compared at various plant densities. Over 3 years, the dry leaf yield improved from 12.36 $\mathrm{Mg} \cdot \mathrm{ha}^{-1} \cdot(3 \mathrm{yr})^{-1}$ with no irrigation, to 13.80 $\mathrm{Mg} \cdot \mathrm{ha}^{-1} \cdot(3 \mathrm{yr})^{-1}$ for microsprinkler irrigation and $15.67 \mathrm{Mg} \cdot \mathrm{ha}^{-1} \cdot(3 \mathrm{yr})^{-1}$ with drip irrigation at a planting density of 111,000 plants/ ha. With the addition of mulch and replanting, microsprinkler irrigation harvest yields increased to $15.25 \mathrm{Mg} \cdot \mathrm{ha}^{-1} \cdot(3 \mathrm{yr})^{-1}$.

Several irrigation monitoring methods are available to growers when managing crop production including pan evaporation (PE), reference evapotranspiration $\left(\mathrm{ET}_{\mathrm{o}}\right)$, or soil water measurements. Soil water measurements can be based on soil water content or SWT. Improved crop yield or reduced water costs can provide incentives for growers to change to more efficient irrigation techniques. Growers of onion (Allium cepa L.) in the Treasure Valley of southwestern Idaho and southeastern Oregon are switching from furrow irrigation to drip irrigation to increase bulb yield and quality (Shock and Shock, 2012). In conjunction with drip irrigation, onion growers also have adopted SWT for monitoring irrigation because SWT is closely related to onion yield and grade (Shock et al., 2000). The SWT measurements help the grower by providing accurate and timely delivery of water to the plant, conserving water while reducing plant water stress, and helping to assure productivity and product quality (Shock and Wang 2011; Shock et al., 2013). This trial explored the effects of SWT irrigation criteria on stevia leaf yield, leaf steviol glycoside content, and steviol glycoside yield. On the basis of results, we hope to develop a protocol for grower irrigation guidelines to realize high leaf and steviol glycoside yields.

\section{Materials and Methods}

This irrigation experiment was conducted at the OSU Malheur Experiment Station, Ontario, OR. The field was Owyhee silt loam (coarse-silty, mixed, mesic Xerollic

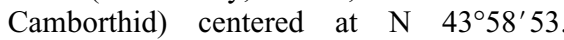
$273^{\prime \prime} \mathrm{W} 117^{\circ} 1^{\prime} 26.396^{\prime \prime}$. A Fall 2014 soil sample indicated that the soil had $\mathrm{pH}$ of 8.0; organic matter $2.23 \%$; available nitrogen $(\mathrm{N})$ $26 \mu \mathrm{g} \cdot \mathrm{g}^{-1}$, phosphorus (P) $26 \mu \mathrm{g} \cdot \mathrm{g}^{-1}$, sulfur (S) $7 \mu \mathrm{g} \cdot \mathrm{g}^{-1}$, and boron (B) $0.7 \mu \mathrm{g} \cdot \mathrm{g}^{-1}$; and exchangeable potassium $280 \mu \mathrm{g} \cdot \mathrm{g}^{-1}$, calcium $3126 \mu \mathrm{g} \cdot \mathrm{g}^{-1}$, magnesium $365 \mu \mathrm{g} \cdot \mathrm{g}^{-1}$, copper $0.7 \mu \mathrm{g} \cdot \mathrm{g}^{-1}$, manganese $(\mathrm{Mn}) 3 \mu \mathrm{g} \cdot \mathrm{g}^{-1}$, zinc 2.9 $\mu \mathrm{g} \cdot \mathrm{g}^{-1}$, and iron (Fe) $9 \mu \mathrm{g} \cdot \mathrm{g}^{-1}$ (Western Laboratories, Parma, ID). The field was then fertilized with $\mathrm{P}$ at $56 \mathrm{~kg} \cdot \mathrm{ha}^{-1}$, potassium hydroxide at $112 \mathrm{~kg} \cdot \mathrm{ha}^{-1}$, elemental $\mathrm{S}$ at $1120 \mathrm{~kg} \cdot \mathrm{ha}^{-1}, \mathrm{Mn}$ at $11 \mathrm{~kg} \cdot \mathrm{ha}^{-1}$, and $\mathrm{B}$ at $1 \mathrm{~kg} \cdot \mathrm{ha}^{-1}$ followed by plowing. In Spring 2015, the field was corrugated into $76-\mathrm{cm}$ beds with the simultaneous installation of drip tape at 8-cm depth. The drip tape consisted of 8-mil tape with emitters spaced at $30.5 \mathrm{~cm}$ and 0.5 $\mathrm{L} / \mathrm{h}$ per emitter flow rate at $55 \mathrm{kPa}$ pressure (Toro Aqua-Traxx; Toro Company, El Cajon, CA). The beds were reshaped with a bed harrow.

Cuttings of 'SW 107' and 'SW 129' were harvested at two separate field locations to provide sufficient rooted cuttings for the trial-the OSU Malheur Experiment Station, Ontario, OR, and the University of California Cooperative Extension Coachella Field Station, Indio, CA. Cuttings were rooted under mist (Shock, 2015) in plug trays containing 162 individual cells filled with sterile Sunshine No. 4 potting mix (McConkey Company, Sumner, WA). Plug trays were placed on $92 \mathrm{~cm} \times 245 \mathrm{~cm}$ galvanized metal trays in a mist chamber that maintained the environment at close to $100 \%$ humidity. Lighting was maintained at 14-h daylength. To prepare the stevia for transplanting to the field, the rooted cuttings were hardened off by slowly reducing the humidity and irrigation while increasing the direct sunlight. On 12 May 2015 , the rooted cuttings of stevia cultivars SW 107 and SW 129 were planted at a spacing of $13.3 \mathrm{~cm}$, placed on alternative sides of the drip tape, resulting in a density of 98,800 plants/ha. The main plots consisted of 200 plants, 100 each of 'SW 107' and 'SW 129'.

The five irrigation treatments were laid out in a randomized complete split-plot design with four replicates. The irrigation treatments were the main plots and cultivars were the split plots. The main plots were four beds wide and 7.6-m long, with 1.5 -m-wide alleys at the end of the plots. A 2-inch $(5-\mathrm{cm})$ irrigation mainline was installed for the trial and subdivided into five separate lines using ball valves, one for each irrigation treatment. Polyvinyl chloride tubing extended from the ball valves to the head of each plot where the tubing was connected to the four drip lines in each plot and operated at $83-\mathrm{kPa}$ pressure. Treatments consisted of five SWT irrigation criteria of $10,20,40,60$, or $80 \mathrm{kPa}$. Five Watermark Monitor data loggers (Irrometer Co. Inc., Riverside, CA) were used to record SWT, one for each irrigation treatment. Two Watermark soil moisture sensors (Irrometer Co. Inc.) were installed at $20-\mathrm{cm}$ depth in each main plot in three of the four replicates. In the other replicate, only one Watermark soil moisture sensor was installed per main plot, due to the limitation of the Watermark Monitors to read up to eight temperature and soil moisture sensors. In total, 35 sensors and 5 temperature probes were installed within the 'SW 129' split plots. The Watermark soil moisture sensors previously had been calibrated to SWT and temperature (Shock et al., 1998). Sensors were read automatically every hour and corrected for soil temperature by the Watermark Monitor. The average SWT readings at 8:00 $\mathrm{Am}$ for each treatment each day were used for irrigation decisions (Fig. 1). During plant establishment, all stevia were irrigated when the soil dried to $20 \mathrm{kPa}$. Starting 8 July 2015, each treatment was irrigated on each morning when the average SWT exceeded its SWT criterion of 10, 20, 40,60 , or $80 \mathrm{kPa}$. Volumetric soil samples were taken adjacent to 15 Watermark soil moisture sensors to develop a relationship between soil water content and SWT. Previous analysis had shown that the SWT at FC was $7.5 \mathrm{kPa}$ and the soil had $12 \%$ volumetric water content at the permanent wilting point.

Initially when the $10-\mathrm{kPa}$ treatment exceeded its criterion, it received 2.5 -h irrigations, then 4-h irrigations from 12 to 18 Aug., and finally 6-h irrigations through the end of the trial. Irrigation amounts above the initial $2.5 \mathrm{~h}$ were adjusted to higher increments because daily water use caused the average 8:00 AM SWT readings to climb near the $20-\mathrm{kPa}$ range in spite of daily irrigations. Once the irrigation durations were adjusted, the 8:00 AM average reading of the $10-\mathrm{kPa}$ treatment fell to within the $10-\mathrm{kPa}$ criterion range (Fig. 1). All other treatments received 6-h irrigations when the treatments' SWT reached their irrigation criteria. The actual irrigation durations were recorded for each irrigation event and the irrigation amounts were estimated based on the drip tape performance at $83 \mathrm{kPa}$ (Table 1; Fig. 2). Hourly SWT data from the sensors were downloaded from the Watermark Monitor data loggers. Concurrently, $\mathrm{ET}_{\mathrm{o}}$ and $\mathrm{PE}$ were monitored and recorded about $200 \mathrm{~m}$ from the trial at the AgriMet and National Oceanic and Atmospheric Administration weather stations on the OSU Malheur Experiment Station, Ontario, OR (Table 2).

The irrigation trial began on 8 July 2015 , when the plants were clipped back to $0.12-\mathrm{m}$ 


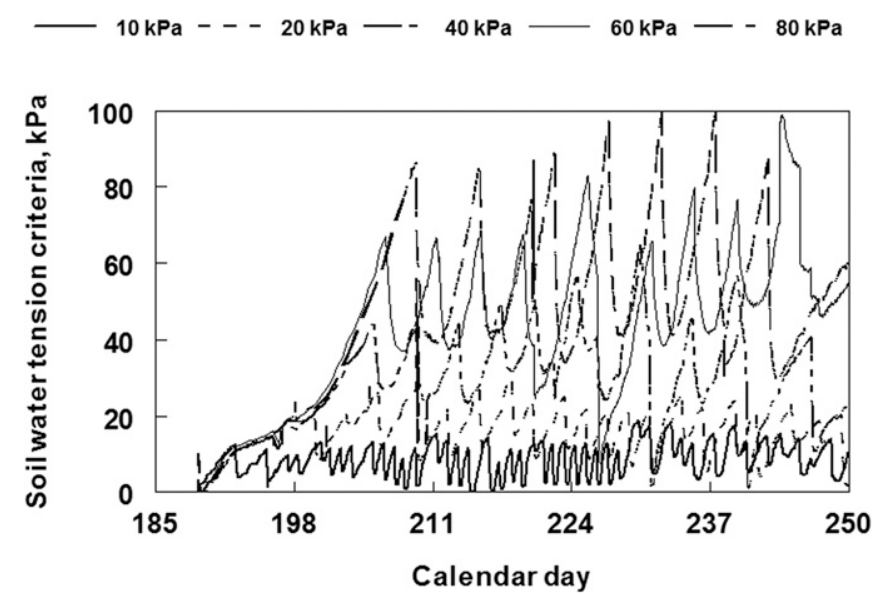

Fig. 1. Soil water tension for 10, 20, 40, 60, and $80 \mathrm{kPa}$ over calendar days 185-262, 8 July to 5 Sept. 2015, Ontario, OR.

Table 1. Water applied to Stevia rebaudiana through five irrigation treatments from 8 July to 1 Sept., 2015, Ontario, OR

\begin{tabular}{lrrrrr}
\hline & \multicolumn{4}{c}{ Irrigation plus precipitation for each irrigation treatment } \\
\cline { 2 - 6 } Portion of the stevia & $10 \mathrm{kPa}$ & $20 \mathrm{kPa}$ & $40 \mathrm{kPa}$ & $60 \mathrm{kPa}$ & $80 \mathrm{kPa}$ \\
\cline { 2 - 6 } irrigation trial & 94 & 52 & 37 & 23 & 22 \\
\hline First 3 weeks & 155 & 141 & 125 & 94 & 48 \\
Second 3 weeks & 112 & 57 & 30 & 30 & 30 \\
Final weeks & 361 & 250 & 192 & 146 & 100 \\
Total & & & & &
\end{tabular}

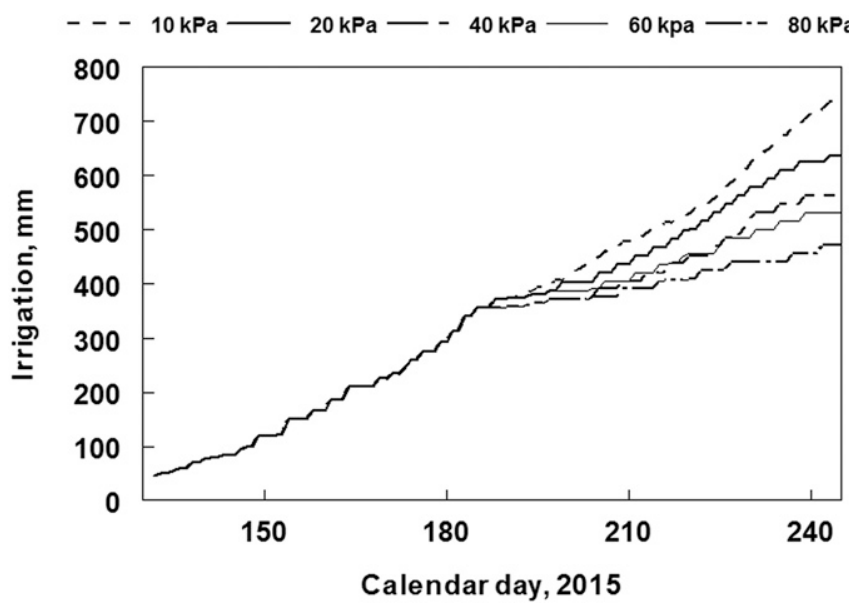

Fig. 2. Accumulated water applied plus precipitation during Stevia rebaudiana crop establishment and during crop response to five soil tension irrigation criteria treatments from 8 July to 5 Sept. 2015 , Ontario, OR.

Table 2. Reference evapotranspiration, precipitation, and pan evaporation during the stevia irrigation trial from 8 July to 1 Sept. 2015 , Ontario, OR.

\begin{tabular}{|c|c|c|c|}
\hline \multirow{2}{*}{$\begin{array}{l}\text { Portion of the stevia } \\
\text { irrigation trial }\end{array}$} & $\mathrm{ET}_{\mathrm{o}}$ & Precipitation & Pan evaporation \\
\hline & \multicolumn{3}{|c|}{ 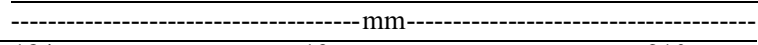 } \\
\hline First 3 weeks & 184 & 13 & 210 \\
\hline Second 3 weeks & 188 & 1 & 209 \\
\hline Final weeks & 109 & Trace & 97 \\
\hline Total & 481 & 14 & 516 \\
\hline
\end{tabular}

$\mathrm{ET}_{\mathrm{o}}=$ reference evapotranspiration.

height and the irrigation treatments were begun according to the treatment SWT criteria. Plant canopy soil cover estimates were made for three separate growing periods. During the first 3 weeks, the trial had less canopy coverage of the soil, because the plants were clipped to $0.12-\mathrm{m}$ height and the soil cover coefficient $(K)$ was observed to be 0.5 . In the second 3 weeks of the trial, canopy covered about two-thirds of the soil and the soil cover coefficient $(K)$ was 0.67 . In the final weeks of the trial, the canopy coverage was complete and the soil cover coefficient $(K)$ was 1.0. The soil surface wetted by the drip irrigation system was never more than 50\%. On 26 May 2015, and again on 16 July 2015 , urea ammonium nitrate $(56 \mathrm{~kg} \mathrm{~N} / \mathrm{ha}$ ) and Sprint 138 (Becker Underwood, Inc., Ames, IA) 6\% iron chelate $(0.012 \mathrm{~kg} \mathrm{Fe} / \mathrm{ha})$ were injected through the drip system. On 28 Aug. 28, all treatments received dissolved zinc sulfate at $0.28 \mathrm{~kg} \cdot \mathrm{ha}^{-1}$.

On 1 Sept. 2015, samples were collected for glycoside analysis and the crop was harvested for yield. Dry leaf samples were tested for nine steviol glycosides (stevioside, rebaudioside $\mathrm{A}$, rebaudioside $\mathrm{C}$, rebaudioside $\mathrm{B}$, rebaudioside $\mathrm{D}$, rebaudioside $\mathrm{F}$, dulcoside A, rubusoside, and steviolbioside) and the analysis methods are described in Parris et al. (2016). To determine yield, $2.13 \mathrm{~m}$ of the two center rows of each subplot were harvested at 0.12-m height after discarding the first 30.5 $\mathrm{cm}$ of border. The plant fresh weight was determined, and a 400- to 600-g subsample of the harvested plant material was weighed, dried, and separated into leaves and stems, and reweighed to calculate leaf yield in $\mathrm{Mg} \cdot \mathrm{ha}^{-1}$. Differences in leaf yield and steviol glycoside content by varying rates of SWT were determined by ANOVA and regression statistics (Hintze, 2007).

\section{Results}

Soil water relationships. Regression analysis showed that the soil volumetric water content, $\ominus_{\mathrm{v}}$, was related to SWT by the following equation:

$$
\begin{aligned}
\ominus_{\mathrm{v}} & =0.120+0.207 \times \mathrm{e}^{-0.0153 \times \mathrm{SWT}}, \\
R^{2} & =0.83, P<0.001
\end{aligned}
$$

The plant available soil water in the upper $0.3 \mathrm{~m}$ of the soil profile between $\mathrm{FC}$ and permanent wilting point was $55 \mathrm{~mm}$ (Tolk, 2003). The percent of plant available soil water, $A_{\mathrm{w}}$ in percent, was related to the soil volumetric water content by the following equation:

$$
A_{\mathrm{w}}=100 \times\left(\ominus_{\mathrm{v}}-0.12\right) / 0.1843
$$

The SWT irrigation onset criteria of 10 , $20,40,60$, and $80 \mathrm{kPa}$ were equivalent to $96 \%, 83 \%, 61 \%, 45 \%$, and $33 \%$ available water for the soil in this field, respectively.

Dry leaf response to irrigation criteria. On the basis of ANOVA, dry stevia leaf yield varied significantly between cultivars' overall irrigation treatments, averaging 5.23 and 4.60 Mg.ha ${ }^{-1}$ for 'SW 107' and 'SW 129', respectively (Table 3 ). On the basis of ANOVA, stevia irrigated at 10 and $20 \mathrm{kPa}$ had significantly higher average leaf yields of 5.68 and $5.24 \mathrm{Mg} \cdot \mathrm{ha}^{-1}$, respectively, than when irrigated at 40,60 , and $80 \mathrm{kPa}$ with total dry leaf yields of $4.63,4.76$, and 4.25 $\mathrm{Mg} \cdot \mathrm{ha}^{-1}$, respectively. Linear regression showed a decline in leaf yield with drier irrigation criteria (Fig. 3). The decline in dry 
Table 3. Leaf yield and steviol glycoside content, ratios, and yield for Stevia rebaudiana in response to cultivar (SW 107, SW 129), soil water tension irrigation treatments $(10,20,40,60,80 \mathrm{kPa})$, and the interaction of cultivars with irrigation treatment, Ontario, OR, 2015.

\begin{tabular}{|c|c|c|c|c|c|c|c|c|c|c|c|}
\hline & $\begin{array}{l}\text { Leaf yield } \\
\left(\mathrm{Mg} \cdot \mathrm{ha}^{-1}\right)\end{array}$ & Stev. $(\%)$ & $\begin{array}{c}\text { Reb } \\
\mathrm{A}(\%)\end{array}$ & $\begin{array}{c}\text { Reb } \\
\text { C (\%) }\end{array}$ & TSG $(\%)$ & $\begin{array}{c}\text { Reb A:Stev. } \\
\text { ratio }\end{array}$ & $\begin{array}{c}\text { Reb A:TSG } \\
\text { ratio }\end{array}$ & $\begin{array}{c}\text { Stev. } \\
\left(\mathrm{kg} \cdot \mathrm{ha}^{-1}\right)\end{array}$ & $\begin{array}{c}\text { Reb A } \\
\left(\mathrm{kg} \cdot \mathrm{ha}^{-1}\right)\end{array}$ & $\begin{array}{c}\text { Reb C } \\
\left(\mathrm{kg} \cdot \mathrm{ha}^{-1}\right)\end{array}$ & $\begin{array}{c}\text { TSG } \\
\left(\mathrm{kg} \cdot \mathrm{ha}^{-1}\right)\end{array}$ \\
\hline \multicolumn{12}{|l|}{ Results by cultivar } \\
\hline SW 107 & $5.23 \mathrm{a}$ & $6.13 \mathrm{a}$ & $7.92 \mathrm{~b}$ & 1.14 & 15.19 & $1.35 \mathrm{~b}$ & $0.52 \mathrm{~b}$ & $325.6 \mathrm{a}$ & $413 \mathrm{~b}$ & $59.8 \mathrm{a}$ & $798 \mathrm{a}$ \\
\hline SW 129 & $4.60 \mathrm{~b}$ & $1.85 \mathrm{~b}$ & $11.38 \mathrm{a}$ & 1.07 & 14.29 & $6.49 \mathrm{a}$ & $0.80 \mathrm{a}$ & $85.8 \mathrm{~b}$ & $532 \mathrm{a}$ & $50.2 \mathrm{~b}$ & $668 \mathrm{~b}$ \\
\hline Average & 4.92 & 3.99 & 9.65 & 1.11 & 14.74 & 3.92 & 0.66 & 205.7 & 473 & 55.0 & 733 \\
\hline LSD $(0.05)$ & 0.56 & 0.46 & 0.6 & NS & NS & 0.67 & 0.02 & 33.1 & 77 & 8.7 & 113 \\
\hline \multicolumn{12}{|l|}{$\begin{array}{l}\text { Results by irrigation } \\
\text { treatment }\end{array}$} \\
\hline $10 \mathrm{kPa}$ & $5.68 \mathrm{a}$ & $4.87 \mathrm{a}$ & 9.63 & $1.20 \mathrm{a}$ & $15.69 \mathrm{a}$ & 3.21 & $0.62 \mathrm{~d}$ & $281.2 \mathrm{a}$ & 548 & $68.7 \mathrm{a}$ & $898 \mathrm{a}$ \\
\hline $20 \mathrm{kPa}$ & $5.25 \mathrm{ab}$ & $4.65 \mathrm{a}$ & 10.24 & $1.16 \mathrm{ab}$ & $16.06 \mathrm{a}$ & 3.45 & $0.64 \mathrm{~cd}$ & $255.5 \mathrm{a}$ & 537 & $62.4 \mathrm{a}$ & $855 \mathrm{a}$ \\
\hline $40 \mathrm{kPa}$ & $4.63 \mathrm{c}$ & $4.05 \mathrm{~b}$ & 9.90 & $1.10 \mathrm{~b}$ & $15.05 \mathrm{a}$ & 3.99 & $0.66 \mathrm{bc}$ & $201.6 \mathrm{~b}$ & 447 & $51.0 \mathrm{~b}$ & $700 \mathrm{~b}$ \\
\hline $60 \mathrm{kPa}$ & $4.76 \mathrm{bc}$ & $3.26 \mathrm{c}$ & 9.10 & $1.00 \mathrm{c}$ & $13.35 \mathrm{~b}$ & 4.55 & $0.68 \mathrm{ab}$ & $159.3 \mathrm{c}$ & 427 & $47.9 \mathrm{~b}$ & $634 \mathrm{bc}$ \\
\hline $80 \mathrm{kPa}$ & $4.25 \mathrm{c}$ & $3.12 \mathrm{c}$ & 9.38 & $1.04 \mathrm{bc}$ & $13.55 \mathrm{~b}$ & 4.41 & $0.69 \mathrm{a}$ & $131.0 \mathrm{c}$ & 403 & $45.0 \mathrm{~b}$ & $579 \mathrm{c}$ \\
\hline LSD $(0.05)$ & 0.60 & 0.43 & NS & 0.09 & 1.09 & NS & 0.03 & 39.5 & NS & 8.7 & 117 \\
\hline \multicolumn{12}{|l|}{ SW 107} \\
\hline $10 \mathrm{kPa}$ & 5.83 & 7.52 & 7.49 & 1.24 & 16.25 & 0.99 & 0.46 & 438.3 & 438 & 72.6 & 949 \\
\hline $20 \mathrm{kPa}$ & 5.67 & 7.19 & 8.38 & 1.21 & 16.77 & 1.17 & 0.50 & 408.0 & 476 & 68.8 & 952 \\
\hline $40 \mathrm{kPa}$ & 5.25 & 6.35 & 8.15 & 1.13 & 15.63 & 1.29 & 0.52 & 332.9 & 427 & 59.2 & 819 \\
\hline $60 \mathrm{kPa}$ & 5.03 & 5.06 & 7.08 & 0.99 & 13.13 & 1.40 & 0.54 & 253.8 & 353 & 49.4 & 656 \\
\hline $80 \mathrm{kPa}$ & 4.36 & 4.52 & 8.53 & 1.12 & 14.16 & 1.90 & 0.60 & 195.0 & 371 & 49.0 & 615 \\
\hline \multicolumn{12}{|l|}{ SW 129} \\
\hline $10 \mathrm{kPa}$ & 5.52 & 2.20 & 11.78 & 1.16 & 15.13 & 5.42 & 0.78 & 124.0 & 659 & 64.9 & 848 \\
\hline $20 \mathrm{kPa}$ & 4.80 & 2.12 & 12.12 & 1.12 & 15.35 & 5.72 & 0.79 & 103.0 & 598 & 55.9 & 757 \\
\hline $40 \mathrm{kPa}$ & 4.00 & 1.75 & 11.65 & 1.07 & 14.47 & 6.68 & 0.81 & 70.3 & 468 & 42.8 & 581 \\
\hline $60 \mathrm{kPa}$ & 4.50 & 1.45 & 11.12 & 1.01 & 13.58 & 7.70 & 0.82 & 64.8 & 501 & 46.4 & 612 \\
\hline $80 \mathrm{kPa}$ & 4.14 & 1.73 & 10.24 & 0.97 & 12.93 & 6.91 & 0.79 & 67.1 & 434 & 41.0 & 542 \\
\hline $\begin{array}{l}\text { LSD }(0.05) \text { cultivar } \\
\text { by treatment }\end{array}$ & NS & 0.59 & NS & NS & NS & NS & 0.04 & 74.0 & NS & NS & NS \\
\hline
\end{tabular}

Stev. = stevioside; Reb A = rebaudioside A; Reb C = rebaudioside C; TSG = total steviol glycoside; LSD = least significant difference; NS = not significant.

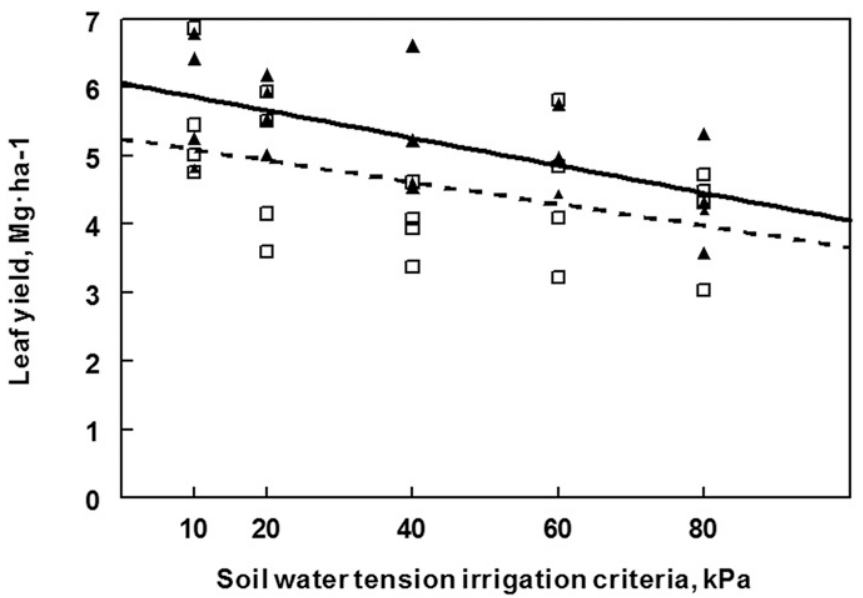

Fig. 3. Leaf yield of two cultivars of Stevia rebaudiana in response to soil water tension irrigation criteria, Ontario, OR, 2015. 'SW 107' $\boldsymbol{\Delta}-\left(y=6.07-0.00201 x, P=0.004, r^{2}=0.37\right)$; 'SW 129' $\square--$ $\left(y=5.26-0.00159 x, P=0.06, r^{2}=0.18\right)$.

leaf yield by SWT for 'SW 107' was highly significant $(P=0.004)$ whereas that for 'SW 129 ' did not reach the $95 \%$ confidence level $(P=0.06)$.

Response of leaf steviol glycoside content to irrigation criteria. Of the nine steviol glycosides tested, stevioside, rebaudioside $\mathrm{A}$, and rebaudioside $\mathrm{C}$ were predominant and are reported here. On the basis of ANOVA, the stevioside leaf content was significantly different between cultivars, with $6.13 \%$ and $1.85 \%$ for 'SW 107' and 'SW 129', respectively (Table 3). Averaged over cultivars, the percent stevioside varied significantly among treatments. The leaf contents from the $10-\mathrm{kPa}$ treatment with $4.87 \%$ stevio- side and the $20-\mathrm{kPa}$ treatment with $4.65 \%$ stevioside were not significantly different, but they were significantly higher in leaf stevioside content than from plants grown at 40,60 , and $80 \mathrm{kPa}$, with $4.05 \%, 3.26 \%$, and $3.12 \%$, respectively. There were also significant differences in the leaf stevioside content for the interaction of cultivar by treatment (Table 3). Regression showed that leaf stevioside declined with drier SWT irrigation criteria $(P=0.0001)$ for both cultivars (Fig. 4).

On the basis of ANOVA overall irrigation criteria, the leaf rebaudioside A content varied significantly between cultivars, with $7.92 \%$ and $11.28 \%$ for 'SW 107' and 'SW 129', respectively (Table 3 ). There were differences in the leaf rebaudioside A content between irrigation treatments as well as among the cultivar by irrigation treatment interaction. Regression analysis showed that leaf rebaudioside A content changed little between irrigation treatments with $P=0.67$ for ' $\mathrm{SW}$ 107 ' and $P=0.30$ for 'SW 129' (Fig. 5).

The leaf rebaudioside $\mathrm{C}$ content averaged over irrigation treatments varied little between cultivars, with $1.14 \%$ and $1.07 \%$ for 'SW 107' and 'SW 129', respectively (Table 3). On the basis of ANOVA, there were significant differences in leaf rebaudioside $\mathrm{C}$ between irrigation treatments. From 10 to $20 \mathrm{kPa}$, there was a minimal rebaudioside $\mathrm{C}$ decline from $1.20 \%$ to $1.16 \%$, but stevia grown at the drier irrigation criteria of 60 and $80 \mathrm{kPa}$ had significantly less rebaudioside $\mathrm{C}$ at $1.00 \%$ and $1.04 \%$ for 'SW 107' and 'SW 129', respectively. There were no significant interactions in rebaudioside $\mathrm{C}$ by cultivar and irrigation treatment (Fig. 6).

On the basis of ANOVA averaged over irrigation treatments, the leaf TSG content was not significantly different between cultivars, with $15.19 \%$ and $14.29 \%$ for 'SW 107' and 'SW 129', respectively (Table 3). By regression analysis, leaf TSG content of ' $\mathrm{SW}$ 107 ' declined significantly with drier irrigation criteria $(P=0.003)$, yet the decline of leaf TSG content for 'SW 129' was not significant $(P=0.09)$ (Fig. 7).

Steviol glycoside ratios in response to irrigation criteria. Averaged over irrigation treatments, the ratio of rebaudioside $\mathrm{A}$ to stevioside in the leaves was significantly different between cultivars, with 1.35 and 6.49 for 'SW 107' and 'SW 129', respectively 


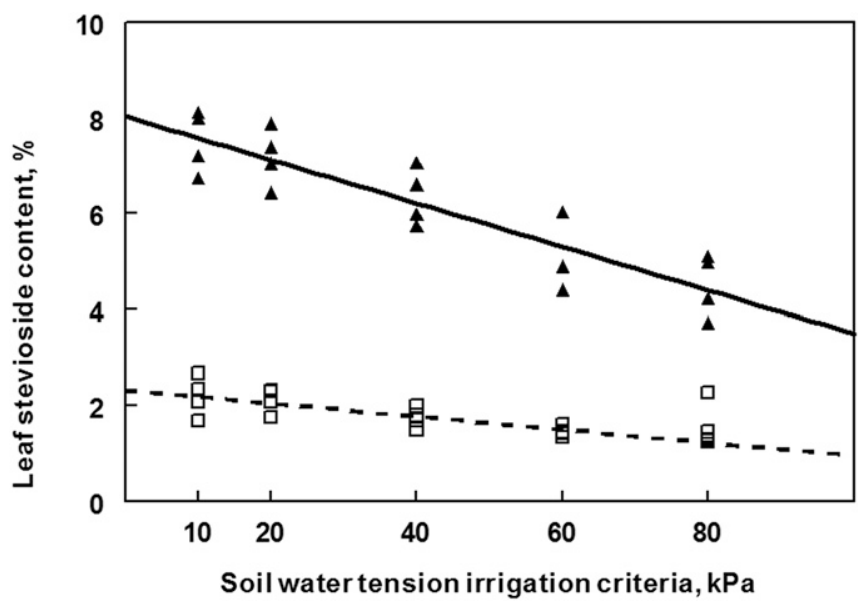

Fig. 4. Leaf stevioside content of two cultivars of Stevia rebaudiana in response to soil water tension irrigation criteria, Ontario, OR, 2015. 'SW 107' $-\left(y=8.03-0.0453 x, P=0.0001, r^{2}=0.80\right)$; 'SW $129^{\prime} \square---\left(y=2.33-0.0137 x, P=0.0001, r^{2}=0.68\right)$.

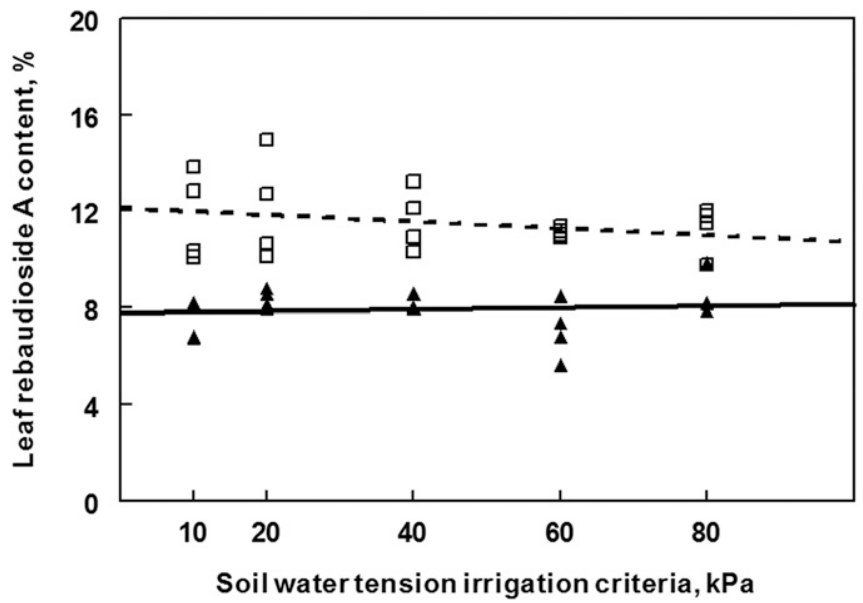

Fig. 5. Leaf rebaudioside A content of two cultivars of Stevia rebaudiana in response to soil water tension irrigation criteria, Ontario, OR, 2015. 'SW 107' $\Delta-\left(y=7.783+0.00346 x, P=0.67, r^{2}=0.01\right)$; 'SW $129^{\prime} \square---\left(y=12.1-0.0138 x, P=0.30, r^{2}=0.06\right)$.

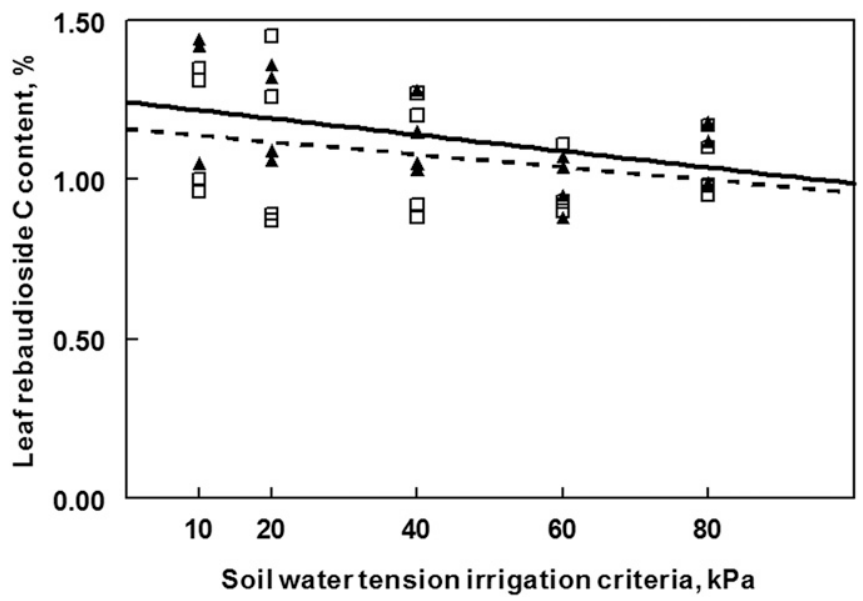

Fig. 6. Leaf rebaudioside C content of two cultivars of Stevia rebaudiana in response to soil water tension irrigation criteria, Ontario, OR, 2015. 'SW 107' $\Delta-\left(y=1.24-0.00256 x, P=0.06, r^{2}=0.19\right)$; 'SW $129^{\prime} \square--\left(y=1.16-0.00198 x, P=0.25, r^{2}=0.08\right)$.

(Table 3). Although ANOVA showed no significant change of the rebaudioside A to stevioside ratio by irrigation treatment or cultivar by treatment interaction, regression analysis indicated a highly significant increase in the ratios of the rebaudioside A to stevioside with drier irrigation criteria for each cultivar $(P<0.001)$ (Fig. 8).

Averaged over irrigation treatments, the ratio of rebaudioside A to TSG in the leaves was significantly different between cultivars, with 0.52 and 0.79 for 'SW 107' and 'SW 129', respectively (Table 3). Over cultivars, the ratio of rebaudioside A to TSG varied significantly between treatments. There were significant differences in the cultivar by treatment interaction. Regression analysis showed highly significant increases in the ratio of rebaudioside $\mathrm{A}$ to $\mathrm{TSG}$ for each cultivar by irrigation treatment $(P<0.001)$ (Fig. 9).

Steviol glycoside yield in response to irrigation criteria. Averaged over irrigation treatments, 'SW 107' and 'SW 129' were significantly different in their yields of the steviol glycosides (Table 3 ) and the patterns of change with irrigation criteria were also different (Figs. 10 and 11). The average steviol glycoside yields for stevioside, rebaudioside $\mathrm{A}$, rebaudioside $\mathrm{C}$, and TSG were $326,413,60$, and $798 \mathrm{~kg} \cdot \mathrm{ha}^{-1}$, respectively, for ' $\mathrm{SW} 107$ ', and 86, 532, 50, and 668 $\mathrm{kg} \cdot \mathrm{ha}^{-1}$, respectively, for 'SW 129'. The regression analysis for 'SW 107' showed a highly significant increase from the drier to the wetter irrigation criteria in the yield of all steviol glycosides: stevioside $(P=$ $0.0001)$, rebaudioside A $(P=0.02)$, rebaudioside C $(P=0.003)$, and TSG $(P=0.001)$ (Fig. 10). For 'SW 129', the increasing trend with wetter irrigation criteria was statistically significant for only stevioside yield $(P=$ $0.002)$ and not for rebaudioside A yield $(P=0.13)$, rebaudioside $\mathrm{C}$ yield $(P=0.13)$, or TSG yield $(P=0.08)$ (Fig. 11).

\section{Discussion}

Cultivar differences. The cultivar SW 107 had significantly greater dry leaf yield, stevioside content and yield per hectare, and TSG and rebaudioside $\mathrm{C}$ yield per hectare than 'SW 129'. In contrast, 'SW 129' had higher rebaudioside A content and yield per hectare, ratio of rebaudioside A to stevioside, and ratio of rebaudioside A to TSG than 'SW 107'. The cultivars did not differ significantly in rebaudioside $\mathrm{C}$ or TSG content. The large differences in stevia cultivar performance in this irrigation trial were consistent with previously reported comparative performance of these cultivars tested at four locations in 2014 (Parris et al., 2016).

Leaf yield. Averaged over cultivars, the dry leaf yield significantly increased from the drier irrigation criteria of 40,60 , and $80 \mathrm{kPa}$ (4.63, 4.76, and 4.25 Mg.ha ${ }^{-1}$, respectively) to the wetter irrigation criteria of $20 \mathrm{kPa}(5.24$ $\mathrm{Mg} \cdot \mathrm{ha}^{-1}$ ) consistent with the SWT criteria responses reported by Niño et al. (2013) in west central Colombia. Lavini et al. (2008), in southern Italy, reported maximum dry leaf yield $\left(4.6 \mathrm{Mg} \cdot \mathrm{ha}^{-1}\right)$ for a treatment watered at $100 \% \mathrm{FC}$ at a density of 50,000 plants/ha. Aladakatti et al. (2012), in southwest India, noted that although the treatment with irrigation at $100 \%$ of class A pan evaporation 


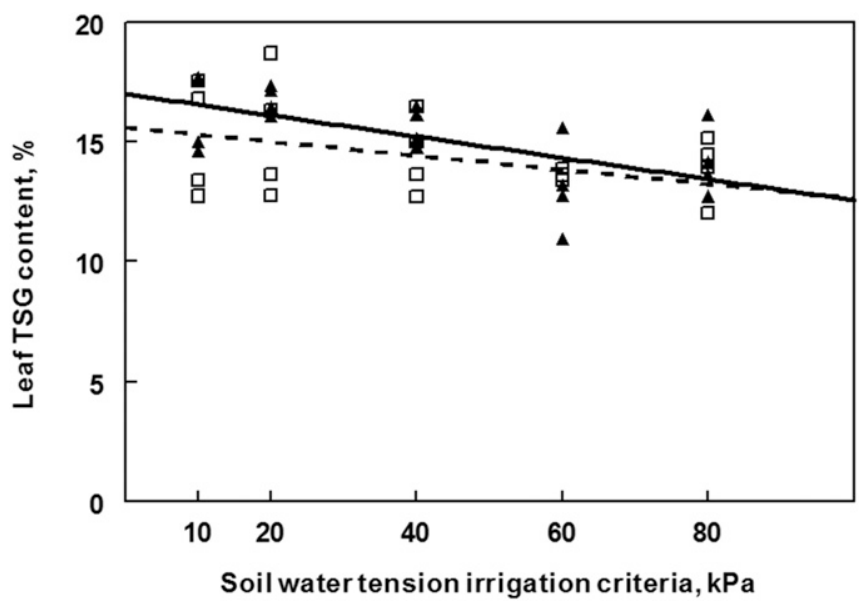

Fig. 7. Leaf total steviol glycoside content of two cultivars of Stevia rebaudiana in response to soil water tension irrigation criteria, Ontario, OR, 2015. 'SW 107' $\mathbf{\Delta -}(y=17.1-0.0445 x, P=0.003$, $\left.r^{2}=0.40\right)$; 'SW 129' $\square--\left(y=15.6-0.0294 x, P=0.09, r^{2}=0.16\right)$.

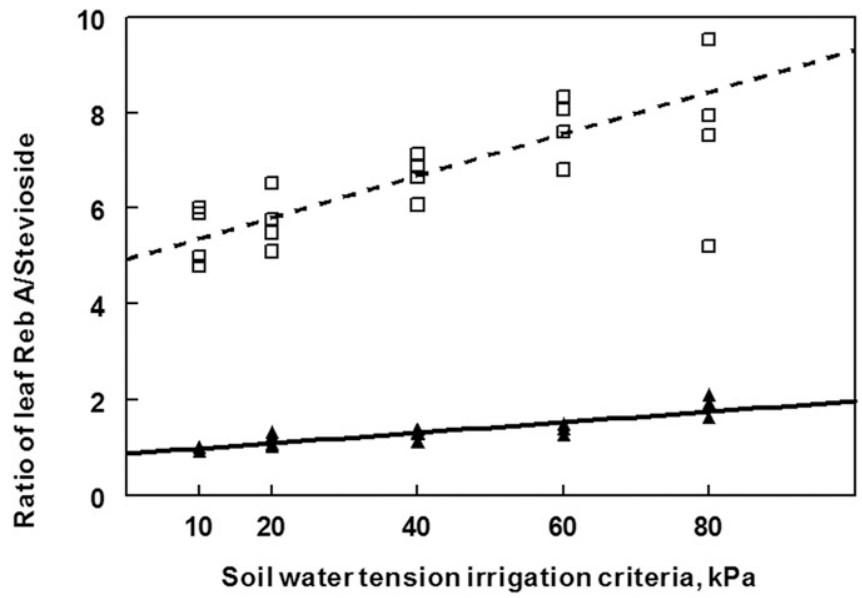

Fig. 8. Ratio of leaf rebaudioside A to stevioside content of two cultivars of Stevia rebaudiana in response to soil water tension irrigation criteria, Ontario, OR, 2015. 'SW 107' $\boldsymbol{\Delta}-(y=0.875+0.0110 x$, $\left.P=0.0001, r^{2}=0.80\right)$; 'SW 129' $\square--\left(y=4.94+0.0438 x, P=0.0001, r^{2}=0.77\right)$.

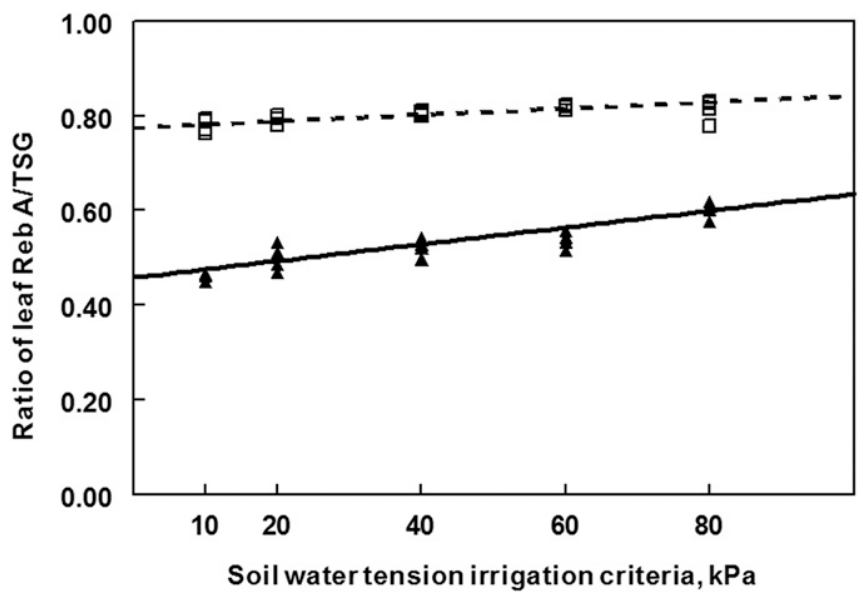

Fig. 9. Ratio of leaf rebaudioside A to total steviol glycoside content of two cultivars of Stevia rebaudiana in response to soil water tension irrigation criteria, Ontario, OR, 2015. 'SW 107' $\boldsymbol{\Delta}-(y=0.458+$ $\left.0.00177 x, P=0.0001, r^{2}=0.83\right)$; 'SW 129' $\square--\left(y=0.775+0.000671 x, P=0.0001, r^{2}=0.78\right)$.

(CPE) had significantly greater dry leaf yield (10.32 Mg.ha $\left.{ }^{-1}\right)$ compared with $80 \%$ CPE $\left(9.36 \mathrm{Mg} \cdot \mathrm{ha}^{-1}\right)$, irrigation at $120 \% \mathrm{CPE}$ did not significantly increase dry leaf yield. Behera et al. (2013), in east-central India, grew stevia at a density of 55,600 plants/ha and found the best dry leaf yields occurred at $100 \%$ CPE with a dry leaf yield of 2.74 $\mathrm{Mg} \cdot \mathrm{ha}^{-1}$.

Stevioside responses. In the current trial, when comparing leaf stevioside content by cultivar, the stevioside content increased significantly from drier to wetter irrigation criteria for both cultivars, but to a lesser degree for SW 129. Niño et al. (2013) observed increases in stevioside at wetter irrigation criteria but their increases were not statistically significant. Lavini et al. (2008) also found no significant differences in stevioside content with irrigation treatment. Karimi et al. (2015) studied stevia under greenhouse conditions in Esfahan, Iran, and found an increase in stevioside when plants were maintained at drier soil water content, in contradiction to the findings of the current trial.

Rebaudioside A responses. In the current trial, leaf rebaudioside A content did not vary significantly with irrigation criteria, consistent with the findings of Lavini et al. (2008) who found no significant differences in rebaudioside A leaf content with irrigation treatments. In contrast, Karimi et al. (2015) showed an increase in rebaudioside A content when plants were maintained at a drier available soil water content of $60 \%$ FC compared with $90 \% \mathrm{FC}$, equivalent to 40 and $14 \mathrm{kPa}$ in the current trial where there was no significant rebaudioside A response.

Ratio of rebaudioside A to stevioside. A greater ratio of rebaudioside A to stevioside has been touted as a desirable cultivar trait (Morita and $\mathrm{Bu}, 2000$ ). Karimi et al. (2015) stated that the ratio of rebaudioside $A$ to stevioside increases as soil moisture levels decrease. This increasing ratio with drier irrigation criteria was evident for both ' $\mathrm{SW}$ 107' and 'SW 129' in the present study. The ratio of leaf rebaudioside $\mathrm{A}$ content to leaf stevioside content reached 7.7 for 'SW 129' when irrigated at $60 \mathrm{kPa}$. The change in the ratio of rebaudioside $\mathrm{A}$ to stevioside in the present study was principally due to decreases in stevioside at drier irrigation criteria, and not increases in rebaudioside A.

Ratio of rebaudioside $A$ to $T S G$. Other authors studying irrigation have not reported the ratio of rebaudioside A to TSGs, even though it is an important ratio in the stevia industry. In the present work, the ratios for both cultivars increased strongly with drier irrigation criteria. These highly significant trends were influenced by decreases in both stevioside and rebaudioside $\mathrm{C}$ content at drier irrigation criteria. But when using regression, the decreases in leaf rebaudioside $\mathrm{C}$ content with drier irrigation criteria did not reach statistical significance for either 'SW 107' $(P=0.06)$ or 'SW 129' $(P=0.25)$.

Total productivity of steviol glycosides. Considering ANOVA averaged over both cultivars, the productivity of stevioside, rebaudioside $\mathrm{C}$, and TSGs increased significantly from drier to wetter irrigation criteria. Rebaudioside A had increased yield per hectare at wetter irrigation criteria, but the differences were not significant. Considering 


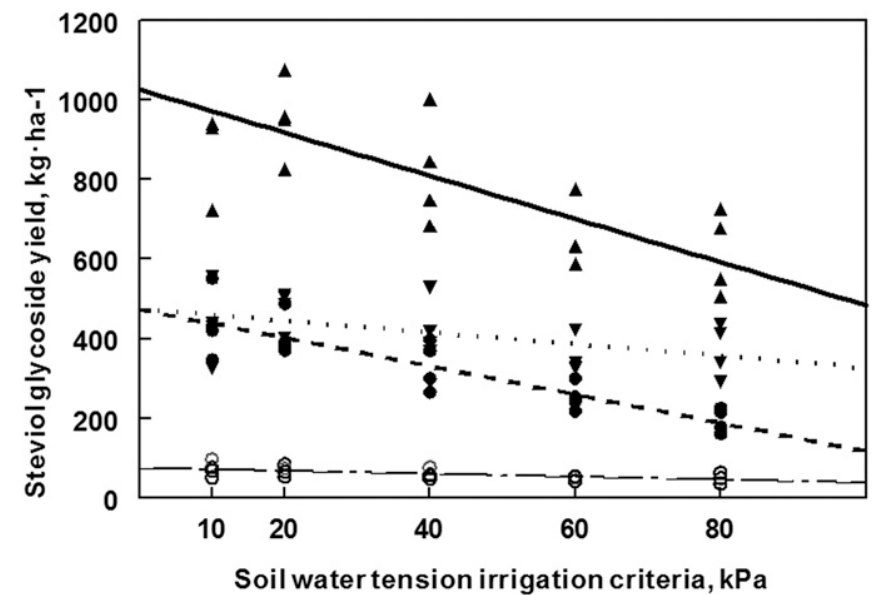

Fig. 10. Yield of steviol glycosides $\left(\mathrm{kg} \cdot \mathrm{ha}^{-1}\right)$ in the leaves of Stevia rebaudiana cultivar SW 107 in response to soil water tension $(\mathrm{kPa})$ irrigation criteria, Ontario, OR, 2015. Total steviol glycosides $\boldsymbol{\Delta}-\left(y=1026-5.42 x, P=0.0001, r^{2}=0.58\right)$; rebaudioside A $--\left(y=475-1.48 x, P=0.02, r^{2}=0.26\right)$; stevioside $\boldsymbol{\nabla}\left(y=475-3.56 x, P=0.0001, r^{2}=0.78\right)$; and rebaudioside $\mathrm{C} \bigcirc \ldots . .(y=75.2-0.367 x$, $\left.P=0.003, r^{2}=0.40\right)$.

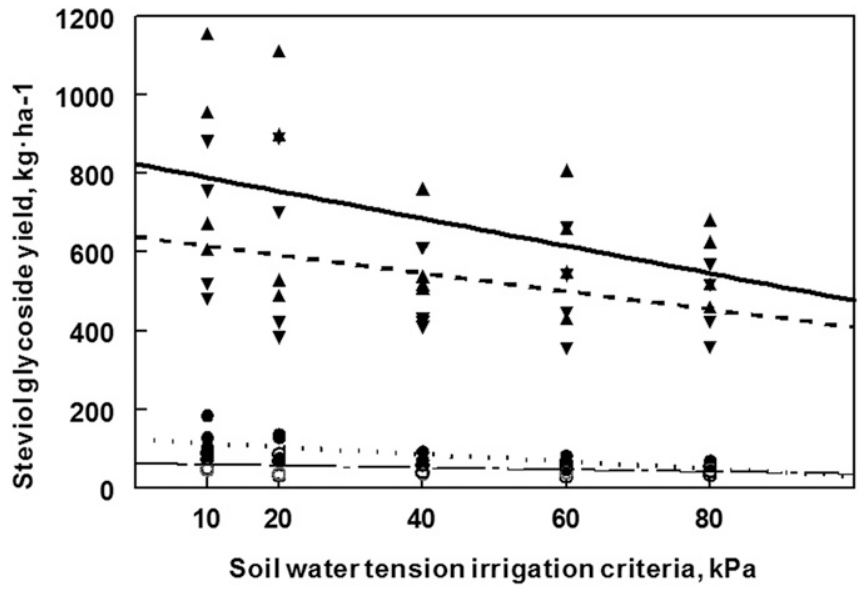

Fig. 11. Yield of steviol glycosides $\left(\mathrm{kg} \cdot \mathrm{ha}^{-1}\right)$ in the leaves of Stevia rebaudiana cultivar SW 129 in response to soil water tension $(\mathrm{kPa})$ irrigation criteria, Ontario, OR, 2015. Total steviol glycosides $\Delta-\left(y=825-3.48 x, P=0.08, r^{2}=0.17\right)$; rebaudioside A - $-\left(y=639-2.30 x, P=0.13, r^{2}=0.13\right)$; stevioside $\mathbf{\nabla}\left(y=123-0.924 x, P=0.002, r^{2}=0.44\right)$; and rebaudioside $\mathrm{C} \bigcirc \ldots . . .(y=61.7-0.254 x$, $\left.P=0.13, r^{2}=0.13\right)$

the regression analyses of steviol glycoside yields by irrigation criteria, the responses differed by cultivar. The cultivar SW 107 had significant yield increases in stevioside, rebaudioside $\mathrm{A}$, rebaudioside $\mathrm{C}$, and TSGs with wetter irrigation criteria. The cultivar SW 129 had significant increases in stevioside yield with wetter irrigation criteria. Although rebaudioside $\mathrm{A}$, rebaudioside $\mathrm{C}$, and TSG contents increased with wetter irrigation criteria, the trends did not reach statistical significance. In the current trial, cultivar SW 129 produced more than $500 \mathrm{~kg} \cdot \mathrm{ha}^{-1}$ of rebaudioside $\mathrm{A}$, consistent with its rebaudioside A yield $554 \mathrm{~kg} \cdot \mathrm{ha}^{-1}$ at Ontario, OR, measured in a previous cultivar evaluation trial (Parris et al., 2016).

Optimum irrigation criteria in terms of $S W T$. The current trial evaluated the effect that SWT irrigation criteria had on dry stevia leaf yield, steviol glycoside content, and steviol glycoside yield. Although stevia cultivars
SW 107 and SW 129 showed significant differences for yield and several of the steviol glycoside components, ANOVA did not reveal a clear picture of the irrigation criteria treatment effects on dry leaf yields or steviol glycoside productivity. Irrigation criteria of 10 and $20 \mathrm{kPa}$ produced the highest yields compared with the drier treatments, but were not significantly different. Regression analysis demonstrated many significant linear trends between irrigation criteria and steviol glycoside traits. For both cultivars, irrigation criteria significantly affected stevioside content, stevioside yield, and the ratio of rebaudioside $\mathrm{A}$ to stevioside, whereas the trends for rebaudioside A content and rebaudioside A yield did not reach the $P=0.05$ confidence level, except for the rebaudioside A yield of SW 107.

When considering a specific irrigation criterion, one has to balance water costs against other production inputs (labor, plant material, and harvest equipment) to maxi- mize the financial benefit to the grower. Where water cost is much lower than other crop production costs, the results indicated that it was better to use the wetter irrigation criteria to maximize stevia productivity. The steviol glycoside of greatest value in the current trial was rebaudioside A. Although the ratio of rebaudioside $\mathrm{A}$ to stevioside increased with drier irrigation criteria, the total yield of rebaudioside A was greater at the wetter irrigation criteria. These results demonstrate that stevia leaf yield and quality sensitively responded to SWT as irrigation criteria, and are similar to the sensitive responses to SWT described for many horticultural crops (Shock and Wang, 2011).

Role of steviol glycosides in osmotic regulation. The limited information developed by the current trial suggests that steviol glycosides are not involved in osmoregulation. In contrast with the results of Karimi et al. (2015), in this trial, TSG increased with wetter irrigation criteria, not in response to osmoregulation.

\section{Conclusions}

The irrigation practices for high leaf and steviol glycoside production from stevia (S. rebaudiana) had not been established in the western United States. This study examined the effect that SWT irrigation criteria had on dry stevia leaf yield and steviol glycoside content. The cultivars SW 107 and SW 129 were evaluated over a 57-d growing period using a drip system and SWT irrigation criteria of $10,20,40,60$, and $80 \mathrm{kPa}$. Results from ANOVA showed that dry leaf yield and most steviol glycoside components significantly increased from higher to lower SWT (drier to wetter) irrigation criteria, yet the delineation between treatments using ANOVA was not clear. Regression analysis showed significant cultivar-specific trends from drier to wetter irrigation criteria for increased dry leaf yield, 'SW 107' at $P=$ 0.0004 and 'SW 129' at $P=0.06$. Stevioside content increased and the ratios of rebaudioside A to stevioside and rebaudioside $\mathrm{A}$ to TSG decreased with wetter irrigation criteria for both cultivars at $P=0.0001$, whereas irrigation criteria did not significantly affect rebaudioside A content for either cultivar. On the basis of regression analysis, the frequent irrigations near $10 \mathrm{kPa}$ produced higher dry leaf yield and rebaudioside A yield, than irrigating at drier SWT criteria.

\section{Literature Cited}

Aladakatti, Y.R., Y.B. Palled, M.B. Chetti, S.I. Halikatti, S.C. Alagundagi, and P.L. Patil. 2012. Effect of irrigation schedule and planting geometry on growth and yield of stevia (Stevia rebaudiana Bertoni)*. Karnataka J. Agr. Sci. 25(1):30-35.

Behera, M.S., O.P. Verma, P.K. Mahapatra, and R.B. Sigandhupe. 2013. Effect of fertigation on stevia (Stevia rebaudiana) under drip irrigation. Indian J. Agron. 58(2):243-250.

Brandle, J.E., A.N. Starratt, and M. Gijzen. 1998. Stevia rebaudiana: Its agricultural, biological, 
and chemical properties. Can. J. Plant Sci. 78 (4):527-536

Casaccia, J. and E. Alvarez. 2006. Recomendaciones técnicas para una producción sustentable del ka'a he'e (Stevia rebaudiana Bertoni) en el Paraguay. Caacupe, Paraguay: Ministerio de Agricultura y Ganadería, Dirección de Investigación Agrícola, Instituto Agronómico Nacional. Manual técnico, ${ }^{\circ} 8.27$ Oct. 2016. $<$ http://www.mag.gov.py/KAA\%20HEE.pdf>.

Fronza, D. and M.V. Folegatti. 2003. Water consumption of the estevia (Stevia rebaudiana (Bert.) Bertoni) crop estimated through microlysimeter. Sci. Agr. 60:595-599.

Goettemoeller, J. 2010. Growing stevia for market. Prairie Oak Publishing, Maryville, MO. ISBN 978-0-9786293-5-9.

Hintze, J. 2007. Number cruncher statistical system 6.0. NCSS 6.0, Kaysville, UT.

Karimi, M., A. Ahmadi, J. Hashemi, A. Abbasi, S. Tavarini, L. Guglielminetti, and L.G. Angelini. 2015. The effect of soil moisture depletion on stevia (Stevia rebaudiana Bertoni) grown in greenhouse conditions: Growth, steviol glycosides content, soluble sugars and total antioxidant capacity. Sci. Hort. 183:93-99.

Lavini, A., M. Riccardi, and C. Pulvento. 2008. Yield, quality and water consumption of Stevia rebaudiana Bertoni grown under different irrigation regimes in southern Italy. Ital. J. Agron. 2:135-143.

Madan, S., S. Ahmad, G.N. Singh, K. Kohli, Y. Kumar, R. Singh, and G. Madhukar. 2010. Stevia rebaudiana Bertoni: A review. Indian J. Nat. Prod. Res. 1(3):267-287.

Midmore, D.J. and A.H. Rank. 2002. A new rural industry-Stevia-to replace imported chemical sweeteners. Rural Industries Research and Development Corporation, Barton, Australia. RIRDC Web Publication No. W02/022. 27 Oct. 2016. <https://rirdc.infoservices.com.au/ downloads/W02-022.pdf>.

Morita, T. and Y. Bu. 2000. Variety of Stevia rebaudiana Bertoni. Assignee: Morita Kagaku
Kogyo Co., Ltd., Osaka, Japan. US Patent 006031157A, 29 Feb. 2000.

Niño, R.J.A., A.J.L. Cuervo, and R.R. Villalobos. 2013. Efecto del potencial mátrico del suelo en el crecimiento del cultivo de estevia (Stevia rebaudiana Bert.). Rev. Colomb. Cienc. Hort. 7(2):240-251. <http://www.scielo. org.co/scielo.php?script=sci_arttext\&pid=S201121732013000200009 \&lang $=\mathrm{pt}>$.

Parris, C.A., C.C. Shock, and M. Qian. 2016. Dry leaf and steviol glycoside productivity of Stevia rebaudiana in the western United States. HortScience 51:1220-1227.

Prieto, P., D. Bonussi, and F. Caniza. 2014. Productividad de ka'a he'e (Stevia rebaudiana Bertoni) con manejo de regio, experienceias en Cooperativa Colonias Unidas. VII Simposio International de Ka'a He'ë - Stevia. 9 Apr. Asunción, Paraguay.

Ramesh, K., S. Virendra, and N. Mergeji. 2006. Cultivation of Stevia [Stevia rebaudiana (Bert.) Bertoni]: A comprehensive review. Adv. Agron. 89:137-177.

Shock, C.C. 1982a. Rebaudi's stevia: Natural noncaloric sweeteners. Calif. Agr. 36:4-5. 27 Oct. 2016. <https://ucanr.edu/repositoryfiles/ca3609p461878.pdf $\$$.

Shock, C.C. 1982b. Experimental cultivation of Rebaudi's stevia in California. Agron. Prog. Rpt. No. 122, Univ. of Calif., Davis. 27 Oct. 2016 $<$ http://www.shockfamily.info/ShockExperimental CultivationOf\%20Rebaudi\%27sSSteviaInCalifornia April1982.pdfs.

Shock, C.C. 2015. Propagation of Stevia rebaudiana by rooted cuttings. Sustainable Agriculture Techniques. Ore. State Univ., Dept. of Crop and Soil Sci. Ext/CrS 154. 27 Oct. 2016. <http://www.cropinfo.net/pdf/extension/ ExtCrs154-SteviaPropogation.pdf $>$.

Shock, C.C., E.B.G. Feibert, and L.D. Saunders. 2000. Irrigation criteria for drip-irrigated onions. HortScience 35:63-66.

Shock, C.C., J.M. Barnum, and M. Seddigh. 1998. Calibration of Watermark soil moisture sensors for irrigation management, p. 139-146. Proc. Intl. Irr. Show. San Diego, Calif. Irr. Assoc. 27 Oct. 2016. <https://www.researchgate.net/ profile/Clinton_Shock/publication/228762944_ Calibration_of_W_ermark_Soil_Moisture_ Sensors_for_Irrigation_Management/links/ 55ed971408ae3e12184819e7.pdf>.

Shock, C.C., R. Flock, E. Feibert, C. Shock, A. Pereira, and L. Jensen. 2013. Irrigation monitoring using soil water tension. Ore. State Univ. Ext. Serv. EM 8900. 27 Oct. 2016. <http://ir. library.oregonstate.edu/xmlui/bitstream/handle/ 1957/37569/em8900.pdf>.

Shock, C.C. and C.A. Parris. 2015. Stevia plant named 'SW 129'. United States plant patent application No. 14757095, filed 17 Nov. 2015. S\&W Seed Co., Fresno, CA, assignee.

Shock, C.C. and C.A. Parris. 2016. Stevia plant named 'SW 107'. United States plant patent US 2016/0157403 P1, published 2 June 2016. S\&W Seed Co., Fresno, CA, assignee.

Shock, C.C. and C.B. Shock. 2012. Research, extension, and good farming practices improve water quality and productivity. J. Integr. Agr. 11(1): $14-30$.

Shock, C.C. and F.X. Wang. 2011. Soil water tension, a powerful measurement for productivity and stewardship. HortScience 46:178185.

Sprinkle, D. 2014. Trends and innovations in sweeteners. Ingredient Marketplace, 2-3 June 2014, New York City, NY. 25 June 2016. <http://www. naturalproductsinsider.com/galleries/2014/07/ slide-show-trends-and-innovations-in-sweeteners. aspx?pg $=2>$.

Tolk, J.A. 2003. Plant available soil water, p. 669672. In: B.A. Stewart and T.A. Howell (eds.). The encyclopedia of water science. Marcel Dekker, New York, NY.

Yadav, A.K., S. Singh, D. Dhyani, and P.S. Ahuja. 2011. A review on the improvement of stevia [Stevia rebaudiana (Bertoni)]. Can. J. Plant Sci. 91(1):1-27. 